\title{
A STUDY AND TREATMENT OF SOME SYRIAN COPPER OBJECTS EXHIBITED IN THE AGRICULTURAL MUSEUM IN CAIRO
}

\author{
Abd Allah, A. \\ Lecturer Conservation dept., Faculty of Fine Arts, Minia Univ., Minia, Egypt \\ E-mail: abeerelalafty@yahoo.com
}

\begin{abstract}
This research examines some Syrian copper objects exhibited in the Museum of Arab Lounge in the Agricultural Museum in Cairo. These objects arrived at the museum during the rule of former President Jamal Abed Al-Nasser (July 1961, when Egypt and Syria united in one country named The United Arab Republic). These objects are six pieces that consist of two bowls, which have writings and decorative inscriptions, two water buckets for carrying water with plants inscriptions, and two trays; one with Koran verses, and the other has inscriptions of battles and wars. All pieces are undated and there is no technical description of them. This research aims also at examining these pieces, treating and maintaining them to clarify the inscription and decorative writings hide behind corrosion compounds and, therefore, studying the possibility of identifying the age to which these Syrian copper objects belong.
\end{abstract}

Keywords: Syrian copper objects, Agriculture museum, Copper alloys, Brass alloy.

\section{Introduction}

Copper and alloys are relatively noble metals that frequently survive adverse conditions [1], including long submersions in salt water that will often completely oxidize copper. Cupreous metals react with the environment to form similar alteration products [2]; copper and alloys in which copper predominates are all generally conserved by the same methods, which metals are conserve[3], particular care needs to be taken only when there is a high percentage of lead or tin in an alloy; lead and tin dissolve in alkaline solutions. So, there are a considerable number of

\subsection{Material}

Calligraphy, Syrian metal antiques characterized by decorative calligraphy. There are three types of calligraphy: the chemical treatments for the conservation of copper and brass [4]. Metal antiques in the Islamic era have through its decorative unity and industrial methods distinctive characteristics for each age and considered as a reflection that embodies the character and features of such age [5]. Therefore, before dealing with the Syrian copper objects as the topic of the research, one should recognize the calligraphy and the Islamic decorative and industrial methods especially those characterizing Mamluk's age in order to facilitate describing and studying these Syrian copper objects.

Solos script (one-third), the copy script and the Cuvee script. As for the Solos script, some believe it called so due to 
comparing its thickness with the thickness of the Tamarisk style, where the thickness of the Tamarisk pen is 24 horse hairs [6] and considered the thickest style that the Copy script group derived from. The thickness of the Solos script is 8 horse hairs; that is one third of the Tamarisk pen. The Solos script considered the master style due to its

\subsubsection{Characteristics of metal antiques in the Mamluk era}

Most of the metal antiques of the Mamluk's age consist of pitchers, plates, pots, water buckets [8], saucepans, pencil cases, trays, chandleries, bowls, censers, lanterns and vases [9]. The Muslim maker reached a high position of accuracy and perfection in the Mamluk's age, which considered as the golden age of metals and copper because MAMLUK Sultans used to care for art and artists in their era. Mamluk's metal objects are easily distinguished among other Islamic eras [10]. Copper objects developed by inlaying golden and silver and using decorative writing on a background of plants stems, branches, and flowers [11].

\subsubsection{Methods of metal production}

During Mamluk's age (648923A.H), art improved and the methods and forms of art were almost similar in Egypt and Sham, according to the methods of production that were common under the AYYUBID era (567-648 A.H.). Many historians believed that they should

\subsubsection{Description of the Syrian copper}

The research includes six copper objects exhibited in the Museum of Arab Lounge. These objects are: - Two bowls, fig. (1-a, b, c) consisting of two sheets of copper, and the external sheet was engraved with plants and geometry decorations. These inscriptions are difficult to describe because they hide under corrosion products, and the inside sheet of the bowls has no inscriptions. Two water buckets shown in fig. (2-a, b, $\mathrm{c}, \mathrm{d})$. Notice that on the top and the bottom of the buckets, there is a strip of plants decorated by engraving. Corrosion products covered the bucket body especially on the bottom of the bucket. Two trays carrying food and contain difficulty, where a calligrapher does not consider a good one unless he masters the Solos script. The Copy script is characterized by being more simple, more flexible, shorter and faster in writing. Concerning the Cuvee script, it ends with an additional part of drawings that look like leafs [7].

That era also characterized by using pairs of birds in organized parts inside containers. Flying ducks were commonly used around formal badges and seals containing the names and surnames of Sultans as well [12]. Copper trays illustrated by having a circular edge just as the Marine Mamluk's age (648-784 A.H.), or a lobular edge consisting of connected arcs common in Mamluk's age (784-923A.H.). The school of Damascus for inlay art in Mamluk's age is famous for medallions with fragmented shapes inside as in the letter (z). The Egyptian and Syrian production of Mamluk's metal objects remained highly accurate [13].

\section{decoration in Egypt and Syria}

be connected together in a single school of art. Simplicity and clarity are prominent features of decorative units and considered as a great tendency towards good quality of decoration. Nevertheless, the two schools are distinctive [14].

\section{bjects before treatment}

silver painting on the edges; one of them has decorative writing by relief drawing and recorded no. (656) in the museum's catalogue, while the other has relief drawings of battles and wars recorded no. (630), fig. (3-a, b, c, d). However, corrosion products largely accumulated on different parts of the two trays. As long as it is difficult to read the decorative writings and to interpret the inscriptions, treating these pieces became a necessity to reveal the inscriptions and to read and interpret the decorative writing in order to facilitate the process of identifying the historical era to which they belong. 

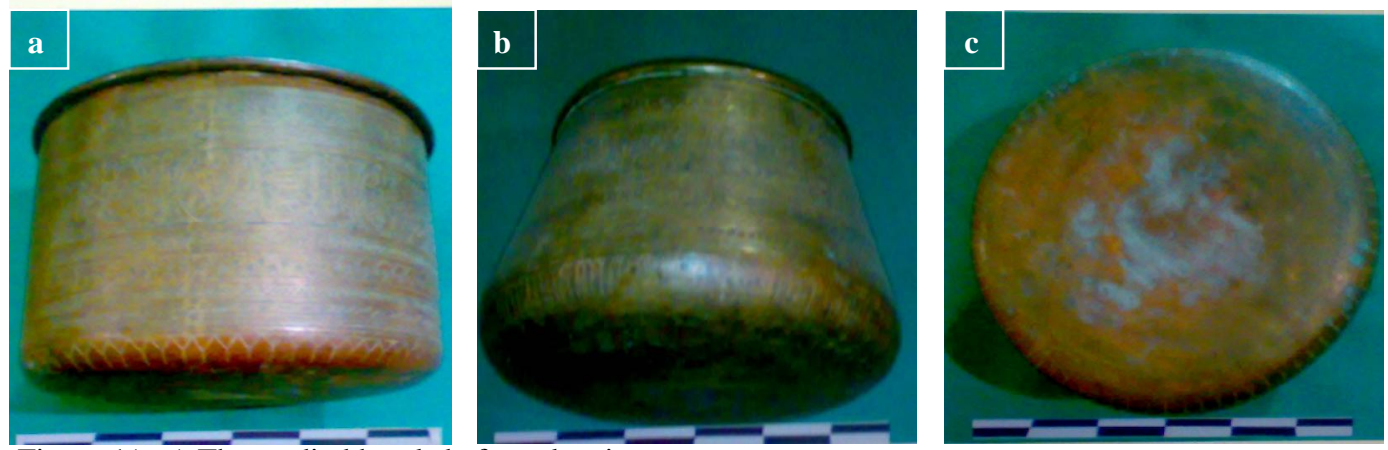

Figure 1(a-c) The studied bowls before cleaning
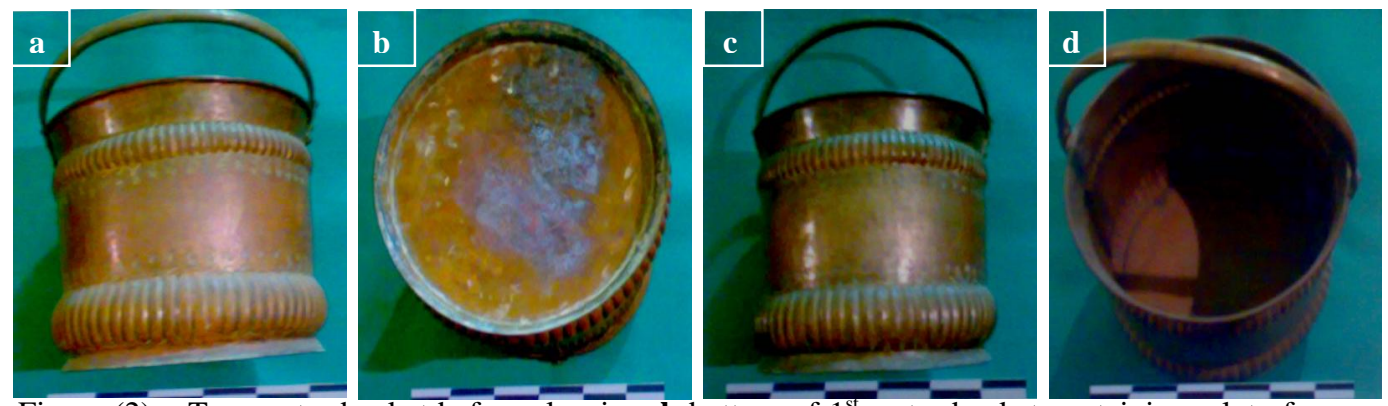

Figure (2) a Two water bucket before cleaning, $\underline{\mathbf{b}}$ bottom of $1^{\text {st }}$ water bucket containing a lot of green corrosion compounds, $\underline{\mathbf{c}}$ the water bucket before cleaning, $\underline{\mathbf{d}}$ different corrosion products inside the second water bucket
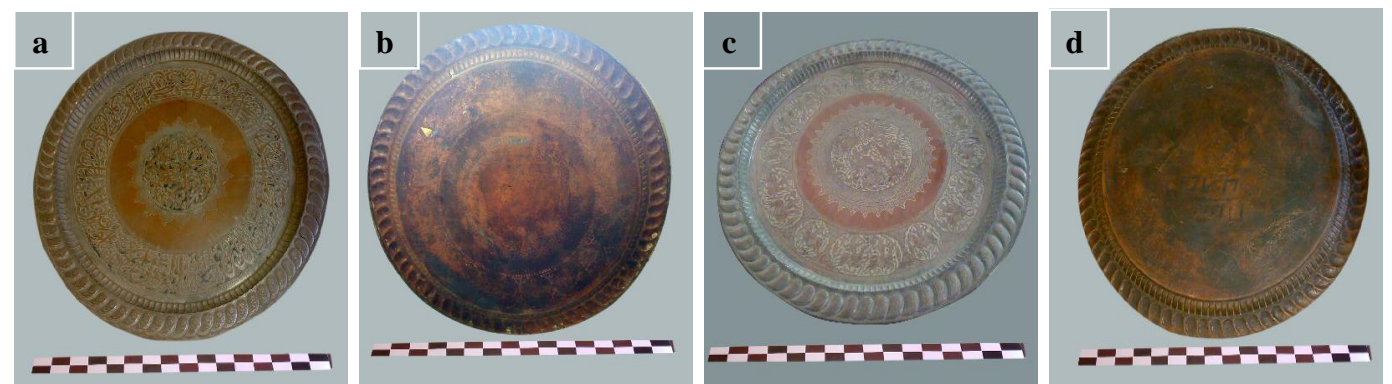

Figure (3) $\underline{\mathbf{a}} \& \underline{\mathbf{b}}$ Two faces of the tray number (656) before cleaning, $\underline{\mathbf{c}} \& \underline{\mathbf{d}}$ two faces of the tray number (630) before cleaning.

\subsection{Treatment}

copper objects (research topic) must be treated and maintained because the writings and inscriptions hide under the corrosion products, Corrosion products reduced by treatment, when mechanical cleaning employed using different brushes as well as scalpels; nevertheless, inscriptions and writings are 1.2.1. Description of the Syrian copper

After treatment, the writings and inscriptions that hide under the corrosion products became clear as follows: a- As for the bowls, fig. (4-a) refers to one of the bowls after treatment procedures, showing that the writings on it separated with a circle containing plants' still hidden. This necessitated the use of chemical cleaning using 10\% Rochelle salt solution, and $10 \%$ Citric acid. The treatment duration took about three months, and then all objects should be thoroughly rinsed with water and dried and finally insulated by using $4 \%$ Polaroid B72.

\section{objects after treatment}

decorations. Engravings used to decorate both bowls. Moreover, the writings were on a background of plants stems and branches using the Solos style. The writings on one bowl read: "Wealth to our Lord- the Sultan- the King- the victorious-Al Nasser- Al Din- Justice- 
Science". The word "Wealth to our Lord" characterizes the Mamluk's era, followed by an engraved decorative strip of the shape "Z", which is another characteristic of the Mamluk's era. As for the other bowls, fig. (4-b) shows the bowls after treatment procedures indicating that the decorations and writings are similar to the previous one except for the text which reads: "The Sultan- Al KHANQAH- the scientist- Al Nasser- the owner- the Justthe Perfect- the owner the Just". The word "KHANQAH" is a Persian translated word which means the place where the Sufi isolates himself to worship God in the Mamluk's era. The KHANQAH of Sultan Al-BARQUQI founded by Sultan Al -Nasser who started it in 801 A.H. in the place where his father Sultan Al- BARQUQI demanded to be buried in one of the most famous KHANQAHS in Cairo. b- , figs. (4-c, d) show water buckets after treatment and maintenance procedures highlighting plants decorations by engraving methods. c- As for the tray recorded in the museum's record under number (656), fig. (4-e) shows the tray after treatment and it became clear that the tray has Silver painting at its edges. The edge distinguished by being lobular, a distinctive feature of the Mamluk's age. Silver inlaying is also used and there are writings at the back of the tray included in the records of the museum and the tray's weight is approximately $12.250 \mathrm{~kg}$. The written text in the Solos style inside the circle reads "The Top of wisdom is the fear of God"; while, on the surroundings of the tray, it reads: "In the name of Allah, the Most Gracious, the most Merciful, my guidance cannot come except from God, in Him I trust, If God helps you, none can overcome you, And there is no victory except from God". As for the tray recorded under number (630), it became clear, after treatment and maintenance procedures as shown in fig. (4-f) that it had relief drawings of battles and wars as well as using couples of birds in organized parts in addition to using flying ducks. All these features distinguish the Mamluk's age.
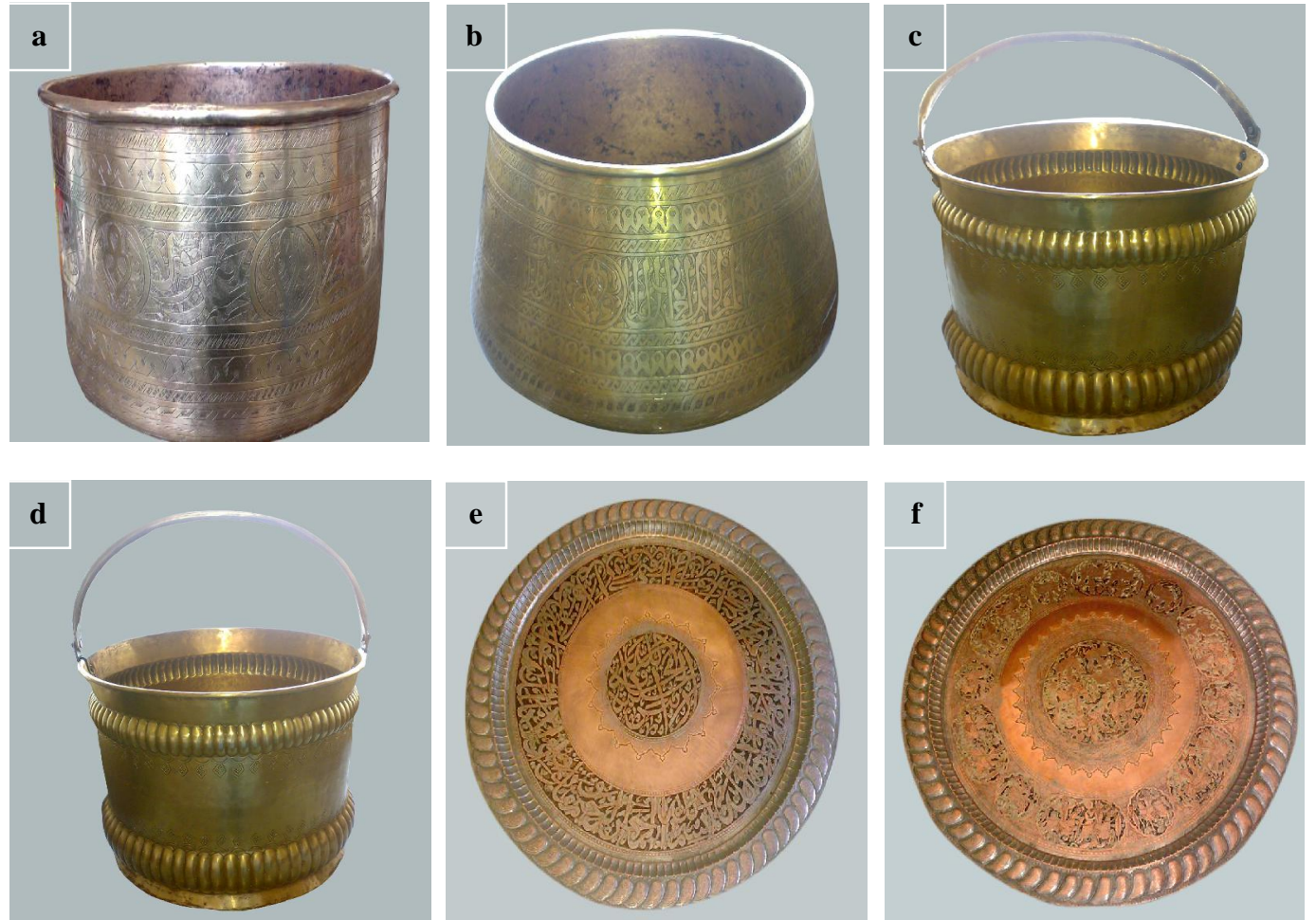

Figure 4 (a-f) The copper objects after cleaning with 10\% Rochelle salt solution and 10\% Citric acid and isolated with $4 \%$ Paraloid B72, so we can read the decorative writings hidden under corrosion compounds. 


\section{Experimental Data}

\subsection{Analysis using X-ray Diffraction (XRD)}

XRD used in the research and analysis to identify the corrosion products using (XPERT-PRO-P Analytical). Figure (5) shows the pattern of XRD which demonstrates that the corrosion products comprise Quartz $\mathrm{SiO}_{2}$, Silicon Oxide, and copper $\mathrm{Cu}$ as well. Calcite $\mathrm{CaCO}_{3}$ or Calcium Carbonate included as a major. In addition, each of the following compounds estimated with high percentages and they represent the corrosion products on the copper objects: (Nantucket), Copper Chloride, and $\mathrm{Cu}_{2} \mathrm{O}$ Copper oxide. The following compounds measured but in low percentages: $\mathrm{Cu}_{2} \mathrm{Cl}$ $(\mathrm{OH})_{3}$, Copper Chloride Hydroxide, and Malachite $\mathrm{Cu}_{2} \mathrm{CO}_{3} \quad(\mathrm{OH})_{2} \quad$ Copper Carbonate.

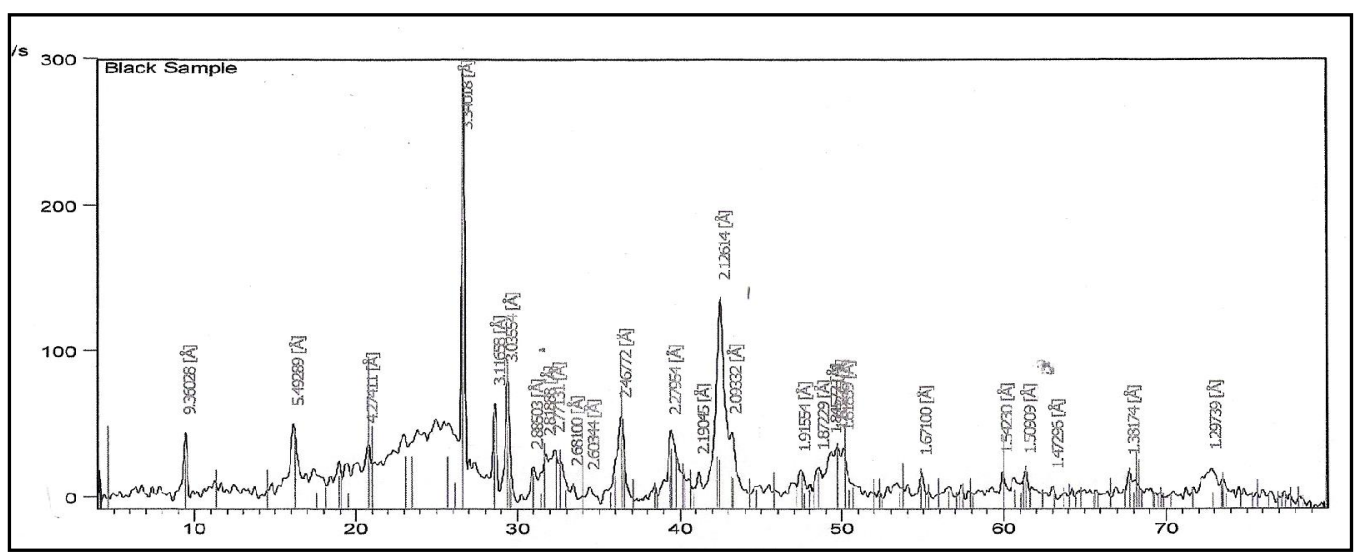

Figure (5) XRD pattern shows the corrosion products consist of Quartz $\mathrm{SiO}_{2}$, Calcite $\mathrm{CaCO}_{3}$, which represents the environment in which the antique existed, Copper $\mathrm{Cu}$ which represents the original metal of the antique, Nantokite, Cuprite $\mathrm{Cu}_{2} \mathrm{O}$ and Tenorite they represent the corrosion products, other compounds Atacamite $\mathrm{Cu}_{2} \mathrm{Cl}(\mathrm{OH})_{3}$, and Malachite $\mathrm{Cu}_{2} \mathrm{CO}_{3}(\mathrm{OH})_{2}$ were also found but in low percentages,:

\subsection{Analysis Using a Scanning Electron Microscope}

Scanning electron microscope (SEM) was used to identify the alloys composition. It was difficult to scratch the objects in order to extract $4 \mathrm{gm}$ for the purpose of analysis by the use of x-ray fluorescence. Therefore (JEOL-JXA840A Electron Probe Microanalysis) used to examine them. As shown in fig. (6-a), it could be noticed the bowl that consists of low percentage of lead that does not dissolve in the copper. EDX of the sample shown in fig. (6-b) points out that it consists mainly of copper $(55.03 \%)$, zinc $(28.51 \%)$, and lead $(5.44 \%)$ which providing the alloy its flexibility and ductility. As for Tin, its percentage is $0.66 \%$ and used to improve the alloy's characteristics and its corrosion resistance. Other minerals found in a percentage that does not exceed $2 \%$, which are most likely impurities (such as silver $0.67 \%$, cadmium $0.51 \%$, titanium
$0.23 \%$, iron $0.64 \%$, and selenium $1.28 \%$ ). Carbon was found with a percentage of $6.21 \%$ which is the adhesive agent used to adhere the sample powder to the device holder. Figure (7-a) shows the brass alloy of tray number (656) containing very low percentage of lead, fig. (7-b). On the other hand, EDX analysis shows that the sample consists mainly of copper $(89.22 \%)$ and zinc $(5.47 \%)$ added to improve the characteristics of the alloy which exemplify the copper Syrian alloys; while tin with a percentage of $(0.40 \%)$ used to improve the characteristics of the alloy and the corrosion resistance; and Lead with a percentage of $(1.31 \%)$ added to improve the flexibility and ductility of the alloy and to facilitate the process of engraving and forming. It also includes number of other minerals that do not exceed $2 \%$ which are most likely 
impurities (such as Silver $0.35 \%$, Titanium $0.23 \%$, Iron $0.60 \%$, and Nickel $0.73 \%$ ), while carbon, the adhesive agent,

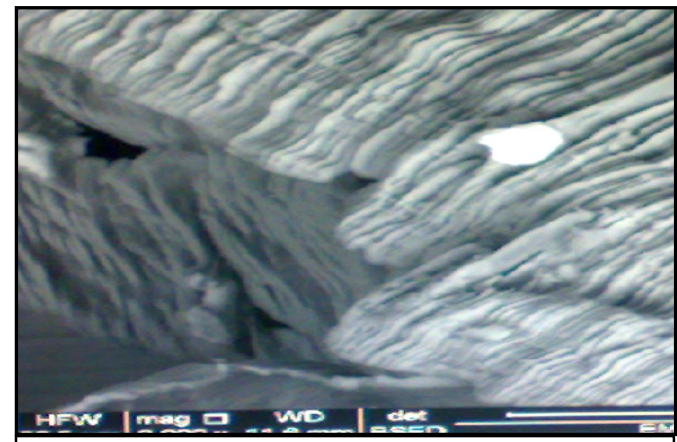

Figure (6-a) Examination of a bowl by SEM shows a low percentage of lead, 3000 $\mathrm{X}$

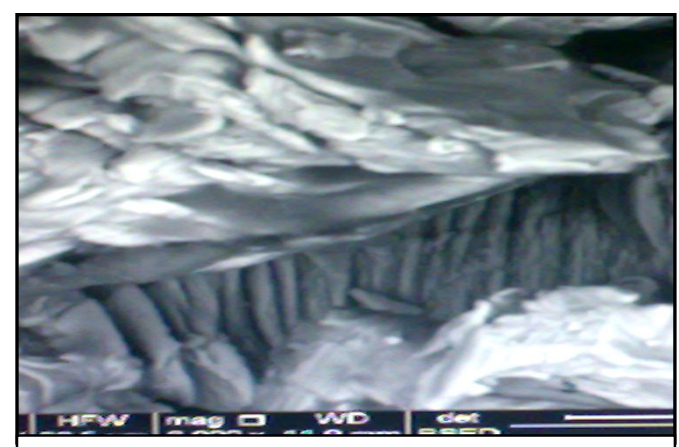

Figure (7-a) Examination of tray number (656) by SEM shows the brass alloy, $3000 \mathrm{X}$

\section{Results}

The previous research and analysis based on SEM, where the brass alloys of Copper and Zinc used to make the Syrian Copper objects. The Syrian brass alloy characterized by having Zinc percentage up to 6\%, while in Egypt the percentage of Zinc in the brass alloys ranges from $10 \%$ to $40 \%$ [15]. The percentage of Zinc in one sample rises to $28.5 \%$ while in the other sample it decreases to $5.47 \%$, where Zinc improves the characteristics of the alloy [16]. It believed that the brass alloy commonly has $30 \%$ Zinc [17], and most historians believed that using Zinc mixed with Copper started at the beginning of 500 B.C [18]. The Romans were the first to use that mixture on a large scale by melting Zinc with Copper and adding other elements to the alloy discovered with a percentage of $0.41 \%$ to adhere the sample powder to the device holder.
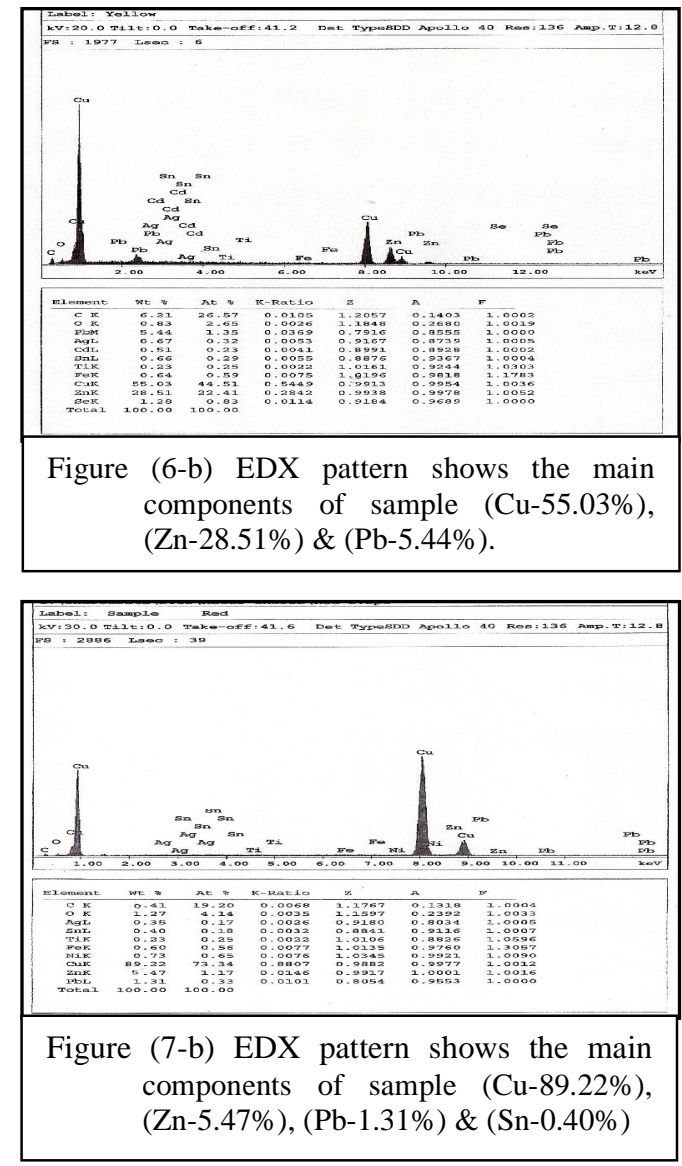

such as Tin at a percentage ranging from $0.1 \%-0.2 \%$ [19]. They beloved that this would improve the characteristics of the alloy and its resistance to corrosion [20], and adding Lead to the alloy would also improve its flexibility and ductility and thus facilitating the process of operation and formation [21]. However, it is clear that the solubility of Lead in Copper is limited [22]. Moreover, the research and analysis using XRD prove that the corrosion products formed on the objects are varied, some of which represent the surrounding environment causing the formation of corrosion in the form of Quartz and Calcite; while others represent corrosion products resulting from erosion such as Nantucket, Cuprites, Atacamite and Malachite. 


\section{Discussions}

The previous analysis proved the Syrian Copper objects consist of brass alloy (alloy of copper and zinc), and the objects had 6\% zinc, which characterized the maker in Syria. After treatment it found the Syrian metal objects characterized by many things that belong to the Mamluk's era, especially the age of King Al Nasser. His name found in the text on one of the bowls. Moreover, the usage of decorative writing on a background of plants stems and branches is a characteristic of the Mamluk's era. On the other bowls a text was written including the word KHANQAH indicating the largest and most famous KHANQAH built in Egypt in the
Mamluk's era. As for the trays, tray no. 630 had decorations of couples of birds and flying ducks which is a characteristic of the Mamluk's era, as well as inscriptions of battles and wars which indicates the instabilities of the country under the reign of King Al-Nasser. The other tray no. 656 refers to such instabilities where some Koran verses and prayers about victory. Solos style used in the decorative writing on all the copper objects. Therefore, the Sols style, the weight of the trays and its decorative units favors the possibility that these objects belong to the age of King AlNasser (801- 815 A.H.).

\section{Conclusion}

Successful research as well as treatment and maintenance processes facilitate identifying the area to which the objects belong, through examining the inscriptions and decorative units of objects with their unique characteristics of the era. On studying and treating the undated Syrian Copper objects exhibited in the agricultural museum, it became clear, through its decorative units and method of production and materials, that the objects characterize the methods of production of the Syrian metal objects in the MAMLUK'S era. The materials, from which these objects formed, as in tray number 656, made of brass with $5.47 \%$ Zinc, which is a characteristic of the old Syrian Copper alloys. These Syrian metal objects are also characterized by many things that belong to the MAMLUK'S era, especially at the age of King Al- Nasser. King Al-Nasser Abu Al-SAADAT FARAJ bin Al- BARQUQ is one of the Sultans of the MAMLUK'S era, who appointed at the age of 13 after his father's death in (801 A.H. 1399 A.H.). Instabilities and seditions were common under his reign particularly in Syria. He built the largest and most famous KHANQAH in Egypt. Sultan Al-Nasser assassinated and replaced in (815 A.H.) by Caliph Al- Moisten B Allah.

\section{Acknowledgment}

The author is grateful acknowledges the help of the engineering Mohamed Allay Al Din the general manger of Agricultural Museum and all the assistants for their kind help in all possible ways.

\section{References}

[1] William, D. \& McAllister, Jr., (1994). Material science and engineering, John Wily \& Sons, Inc., New York.

[2] West, E. \& Weld, F., (1982). Copper and Its alloys, John Wiley, \& Sons, New York

[3] Hamilton, D., (1999). Methods of conserving archaeological material from underwater sites, A \& M University, Texas, USA.

[4] Rutledge, J. \& Gordon, R., (1987). The work of metallurgical artificers at Macho Picher, Peru, American Antiquity, Vol. 52 (3), pp: 578- 594
[5] Trigger, B., (1993). Early civilizations ancient Egypt in context, the American Cairo Univ. Press, Egypt.

[6] Abed al Halim, H., (1984). Old Arabic writings: A study in the form and content, Madbouli library, Cairo.

[7] Ziemech, S., (2004). The Mamluks in history, FSTC limited, UK

[8] Elizabeth, G. \& Steve, E., (1981). Art of the Mamluks, Saudi Armco world Magazine, Vol. 81, pp: 2-9.

[9] Mohamed, E., (2012). Mamluk's metal, http/www .civilization lovers. 2/8/2012. 
[10] Jonathan, M., (1999). Mamluk art and architectural history: A review Article, East documentation center, Mamluk Studies Review, Vol. 3, pp: 31-58

[11] Archaeologists Islamic, (2009), Islamic archaeology, http//www.aregy.com, $5 / 4 / 2009$

[12] Lamaan, B., (2004). Introduction to Muslim art, FSTC limited, UK.

[13]Allan, J., (2012). Metalwork and metal culture in the Islamic world, L.B.Tauris Ltd, London.

[14] Abouseif, D., (2005). VenetoSaracenic Metalware, a Mamluk Art, Mamluk Studies Review, Vol. 9 (2), pp: $147-172$

[15] Carddock, P., (1995), Early Metal Mining and Production, Smithsonian Institution Press, USA.

[16] Scott, D., (1990). Bronze disease: a review of some chemical problems and the role of relative humidity, JAIC, Vol. 29 (2), pp: 193-206.

[17] Ganorkar, M., Pandit Rao, V., Gayathri, P. \& Sreenivasa Rao, T., (1988). A novel method for conservation of copper and copperbased artifacts, Studies in conservation, Vol. 33 (2), pp: 97-101

[18] Denny, J., (1996). Principles and prevention of corrosion, Prentice Hall, 1996, USA.

[19] Lucey, V., (1972). Developments leading to the present understanding of the mechanism of pitting corrosion of copper, British Corrosion Journal, Vol. 7 (1), pp: 36-41(6)

[20] Cronyn J., (1990). The elements of archaeological conservation, TJ Press, Rutledge.

[21] Stambolov, T., (1985), The Corrosion and conservation of metallic antiquities and works of arts: A preliminary survey, Central Research Laboratory for Objects of Art and Science, Amsterdam.

[22] Angelucci, S., Fiorentino, P., Ksinkova, J., \& Marabelli, M., (1978), 'pitting corrosion in copper and copper alloys: comparative treatment tests', Studies in Conservation, Vol. 23, pp: 147-156. 